BOTANICA

ISSN 2538-8657

2020, 26(1): 101-108

\title{
PROFESSOR POVILAS SNARSKIS - LIFE DEDICATED TO THE RESEARCH OF LITHUANIAN FLORA
}

\author{
Jūratė TuPČIAuSKaIté, Radvilè RIMGAILĖ-VoICIK*
}

Vilnius University, Life Sciences Centre, Institute of Biosciences, Sauletekio Av. 7, 10257 Vilnius, Lithuania

*Corresponding author. E-mail: radvile.rimgaile-voicik@gmc.vu.lt

\begin{abstract}
Tupčiauskaitė J., Rimgailè-Voicik R., 2020: Professor Povilas Snarskis - life dedicated to the research of Lithuanian flora. - Botanica, 26(1): 101-108.

The paper presents a brief biography of Professor Povilas Snarskis, and discusses the importance of his work for Lithuania. After defending PhD at Vytautas Magus University, P. Snarskis was able to collect invaluable data on the Lithuanian floristic diversity and distribution. He actively participated in the development of the Lithuanian higher education. In 1947, he became a professor and taught botany at Vilnius University and Vilnius Pedagogical Institute. During his professional career, P. Snarskis has published about 60 research and popular science works. He was a co-author of Flora of Lithuanian SSR and his three guides to native vascular plants still have their high value. The number of Snarskis' herbarium specimens deposited at Vilnius University Herbarium (WI) and the Nature Research Centre, Institute of Botany Herbarium (BILAS) exceeds 20.000. P. Snarskis was an innovator, who used his logic and creativity, and constructed guidelines to achieve his goals in difficult historical times.
\end{abstract}

Keywords: Alchemilla, biography, herbarium, history of science, plant geography.

"You have to prepare before going to nature. Similarly, like people did before going to the church in the early days: take a bath, get dressed well and have a good will" used to say Professor Povilas Snarskis to his students (JANONIS, 1999).

In 2019 , we commemorated the $130^{\text {th }}$ anniversary of the birth and $50^{\text {th }}$ anniversary of the death of the famous Lithuanian botanist Professor Povilas Snarskis (1889-1969). In the middle of the chaos of the 20 th century, P. Snarskis was able to collect invaluable data on the floristic diversity and its distribution in Lithuania. He actively participated in the development of Lithuanian higher education and the formation of professional Lithuanian plant sciences at Vilnius University (VU) and Vilnius Pedagogical Institute (later Pedagogical University).

Povilas Snarskis was born on 25 August 1889 in Švobiškis village, present Pasvalys district, Lithuania. After graduating from Švobiškis Primary School,
P. Snarskis studied at Joniškèlis Agricultural School. In 1910, after graduating from the Panevėžys Teachers' Seminary (LCSA), he became an active member of the Lithuanian Teachers' Union. In 1910-1919, P. Snarskis taught in primary schools, and in 1920-1925, he worked at Joniškèlis Agricultural School. In his memory, Vytautas Gudonis made a roofed pillar in the yard of Joniškèlis Agricultural School (ANONYMous, 2019a).

P. Snarskis desire to study at university was postponed by the First World War, because in 1914 he was admitted to the Russian Imperial Army and returned to Lithuania only in 1918 (ButKus \& MERKYs, 1999). In 1924, P. Snarskis applied to study as a free listener (Fig. 1) at the University of Lithuania in 


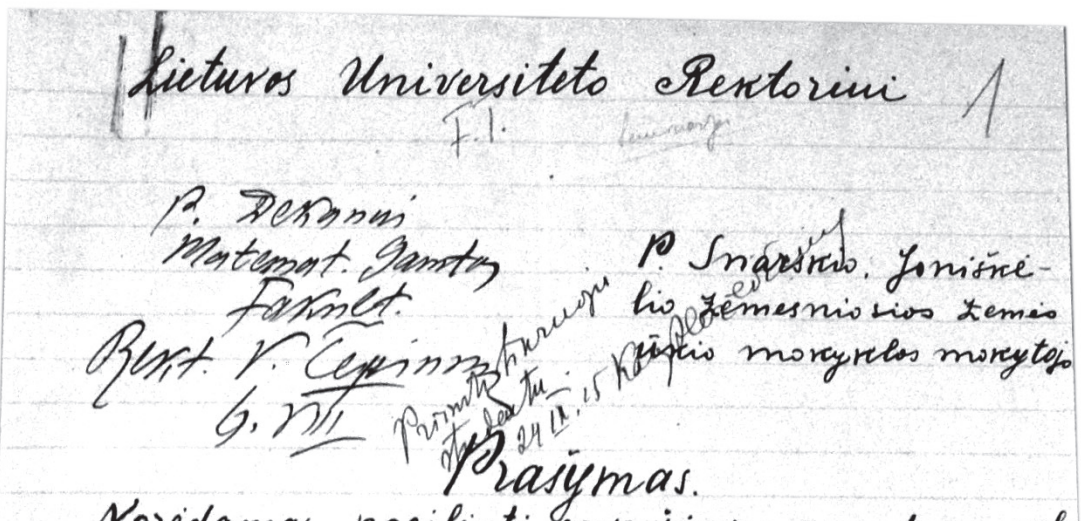

Noredamas pagilinti savo iinias gamtos moxsly sritye, turiu garbis prasyti Famsta priemti mane laisrus in relausytojin is Matematircos-Gamtos faxulteto biologifos scyrie, pirmg semestrg.

osu baiges Pancreñi morytojus seminarijas; sefotynerius metus morytojarau pradžios mory relose on dabar retrirtus metus morytojanju Jonisicelio

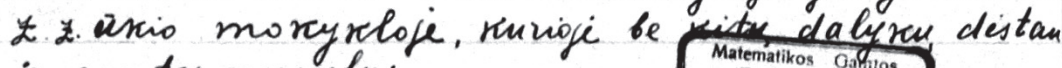
ir gamtos morslus.

\section{Priedas:}

$1)$ Panerešio morytojis paxymejimas.

2) Netrins istraurea

3) Dilietybis liudymas.

4) Z. Ü is V.T. Ministerifos Žemes sinio Despartamento liudymas.

5. Trys fotografijos

Yonisixiclis, Pasr apsson.

$$
\text { P Snarskis }
$$

$1924 \mathrm{~m}$. liepos min $29 d$.

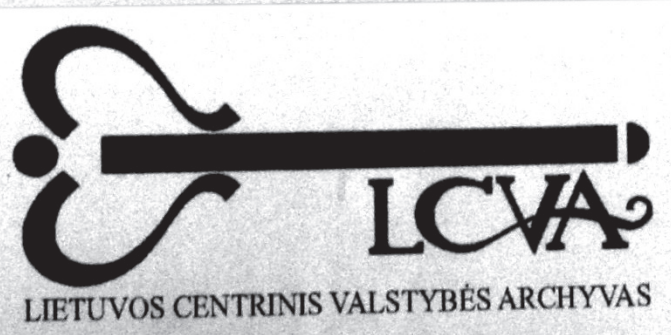

Fig. 1. Povilas Snarskis' handwritten application to enter the University of Lithuania as a free listener, kept in the office of the Chief Archivist of Lithuania (Vytautas Magnus University student files, LCSA F631/7/839/1) 
Kaunas (now Vytautas Magnus University; VMU), Faculty of Mathematics and Natural Sciences, Department of Biology. Since 1928 Snarskis began collecting data on the diversity, prevalence and ecology of vascular plants. At that time, he was working on his diploma work on the distribution of Alchemilla aggr. vulgaris L. in Lithuania. He started from the flora of the surroundings of his native village (Northern Lithuania), later he explored Kaunas county. In 1929 , P. Snarskis, at the age of 40, completed eight semesters of biology studies with good and excellent grades (LCSA) and obtained a degree in plant geography (RIČKIENĖ, 2017).

Ten years after graduating from university, P. Snarskis worked as a teacher at Vytautas Magnus Klaipèda Gymnasium and Klaipeda Trade Institute. He taught biology, chemistry, physics and mathematics. Povilas Snarskis devoted thirty years (from 1910 to 1940) to teaching, but his personality could not come to terms with the occupation. According to contemporaries, he was a gifted naturalist with a mathematical rationality; he had the stamina and diligence required for scientific work and life in general (Butkus \& Merkys, 1999). After graduating from the University and working as a lecturer, P. Snarskis, encouraged by Prof. C. Regel, started collecting data for his dissertation on the genus Alchemilla L., the diversity of which was utterly unknown in Lithuania at that time (SNARSKIS, 1939). He spent his summer holidays and other free time researching Lithuanian flora. While preparing his doctoral dissertation, he studied Klaipeda county and later also additional places connected by railways Klaipèda-Šiauliai, Šiauliai-Biržai and Klaipėda-Kaunas. He organized excursions for more remote locations. P. Snarskis searched for habitats on foot or by horse-drawn carriage. He visited a total of 2.161 sites at a distance of at least $5 \mathrm{~km}$ and collected 3.835 herbarium specimens (SNARSKIS, 1939). P. Snarskis soon became known as an insightful flora researcher, taxonomist and plant geographer.

During the interwar period, studies of Lithuanian flora were organized at the University of Lithuania, and the theoretical goals of Lithuanian botany were formulated under the leadership of Professor Constantin Andreas von Regel (1890-1970) (KLIMAVIČIŪTĖ, 2002). By 1940, under the direction of Prof. C. Regel at VMU, P. Snarskis defended his doctoral dissertation
"Lady's Mantle (Alchemilla) plants and their distribution in Lithuania" (Fig. 2). In this work, P. Snarskis discussed Alchemilla spp. diversity in Lithuania and first prepared and published maps of the distribution of plant species in independent Lithuania; the maps were designed for Alchemilla species.

Atspausdinta is̆ V.D.U. Matematikos-Gamtos F-to Darbu 1939, XII t., 2 sass.
Extrait des „Mémoires de la Faculté des Sciences de P'Université Vytautas le Grand" 1939, volume XIII, fasc. 2.

\section{P. S N A R S K I S}

\section{LIETUVOS RASAKILOS (ALCHEMILLA) IR JŲ IŠSIPLATINIMAS}

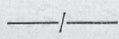
DIE LTTAUISCHE ALCHEMILLA - ARTEN UND
IHRE VERBREITUNG

DISERTACIJA

Daktaro laipsniui isigyti

\section{KAUNAS - Kooperatiné „Raidés“ spaustuvė Kaune • 1939}

Fig. 2. Cover page of Povilas Snarskis' doctoral dissertation "Lady's Mantle (Alchemilla) plants and their distribution in Lithuania" prepared under the direction of Prof. Constantin Regel at Vytautas Magnus University

After 1940, P. Snarskis worked at the Department of Natural Sciences of Vilnius University (19401967) and Vilnius Pedagogical Institute (1944-1952) (Fig. 3). P. Snarskis together with other botanists organized the Faculty of Natural Sciences and Geography of Vilnius Pedagogical Institute and was the first dean of the Faculty of Natural Sciences and the head 
of the Department of Botany (ButKus \& MERKYs, 1999; RIČKIENĖ, 2003). In 1947, P. Snarskis became a professor at Vilnius University (KLIMAVIČIŪTĖ, 2002), gave lectures on plant systematics, plant geography, history of biology, courses on the methodology of natural sciences, organized plant research excursions with botany students (RIČKIENĖ, 2003). As the head of the VU Department of Darwinism and Genetics, P. Snarskis had to manoeuvre between the politically enforceable Michurinist biology and Mendel laws theory (RIČKIENĖ, 2017). At that time he began research into introduced plants and made many contributions in this area.

P. Snarskis contributed to the research of Lithuanian flora by collecting herbaria. According to JANKEVIČIENĖ \& LAZDAUSKAITĖ (1999), approximately 12.000 herbarium sheets were donated by P. Snarskis to the Herbarium of the Institute of Botany (BILAS) of the Lithuanian Academy of Sciences. About 10.000 herbarium sheets were deposited at
Vilnius University Herbarium (WI). P. Snarskis' herbarium collection could hold up to 30.000 specimens, but part of it was destroyed. To our knowledge, the actual number of P. Snarskis' specimens deposited at Lithuanian herbaria has never been verified; we know from the published material that in 1952 and 1969 the numbers of herbarium sheets deposited at BILAS were respectively 8080 and 3680 , and since 1952 there were about 1000-1500 sheets of the herbarium per year and that in the mentioned year P. Snarskis deposited his personal collection at BILAS (JANKEVIČIENĖ \& LeKAVIČIUS, 1977).

Prof. Regel's work (1922-1940) in Kaunas led to the first generation of professional botanists. The first valuable work of his students was the manual for Lithuanian vascular plants (KUPREvičIUS, 1934), which describes 903 native and 243 more common introduced species and 170 species that may occur in Lithuania (JANKEVIČIENĖ \& LAZDAUSKAITĖ, 1999). After the World War II, in 1948, based on his her-

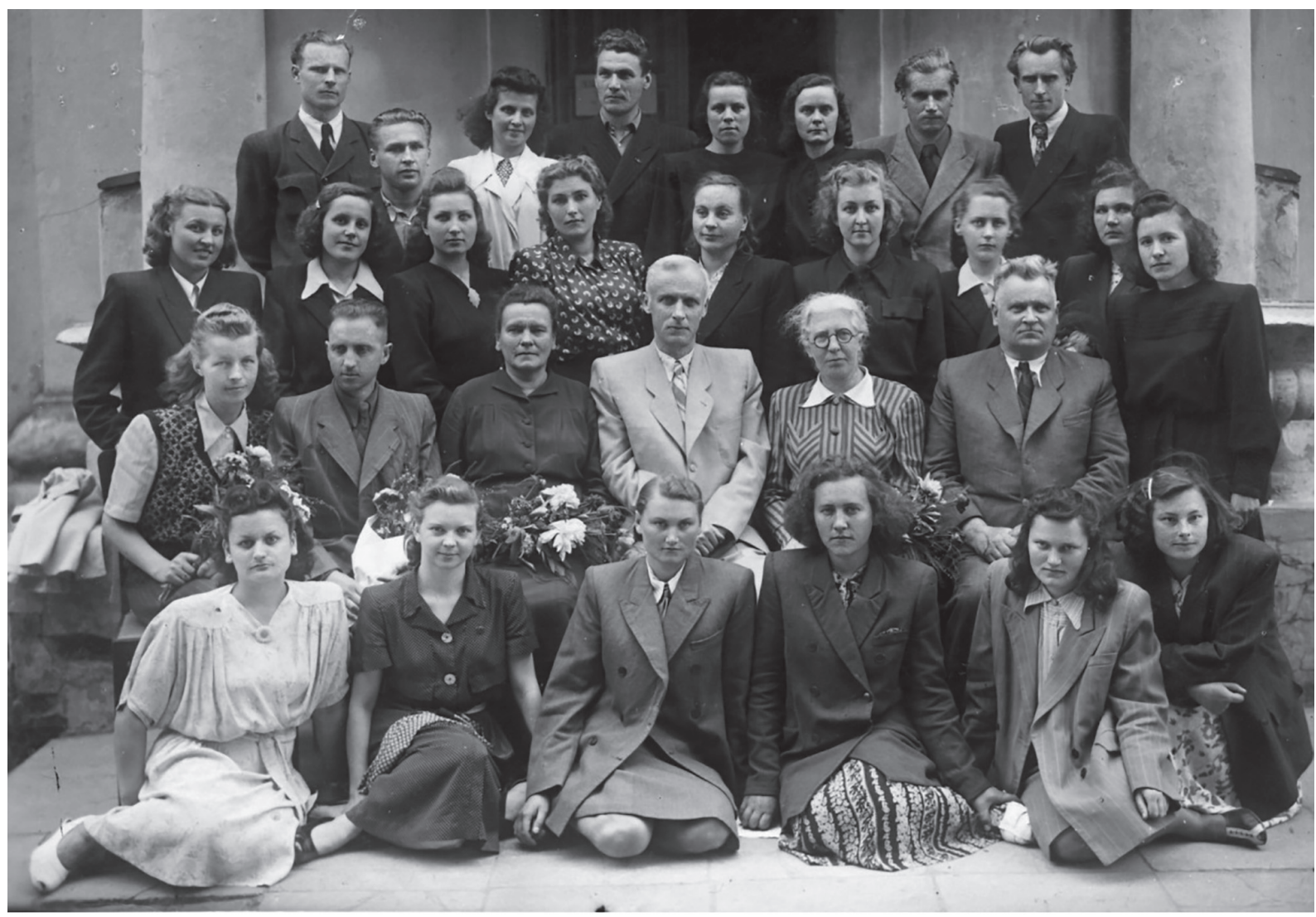

Fig. 3. Povilas Snarskis (sitting first from the right) with lecturers of the Faculty of Natural Sciences and Geography of Vilnius Pedagogical Institute and graduates of the 7th generation biology-chemistry speciality, June 1952 (photo submitted by Silva Žilinskaitè, Vilnius University Botanical Garden, an unpublished archive of Povilas Snarskis) 
barium collections and accumulated professional botanical knowledge of botany, P. Snarskis published a special guide for weeds of cultivated fields in Lithuania (SNARSKIs, 1948). Besides descriptions of 380 vascular plant species, he dedicated a considerable part of the focus to common plant organography. The range of species presented was much larger than might be expected, including important grassland and forest species that may occur in anthropogenic habitats. Later P. Snarskis' guide on the knowledge of Lithuanian vascular plants (SNARSKIS, 1954) was published with all known native (about 1500), introduced (about 600) and 72 species that can be found in Lithuania according to their distribution in neighbouring countries (JANKEVIČIENĖ \& LAZDAUSKAITÉ, 1999). Species, the occurrence of which in Lithuania was known from the literature, were also included. In the guide, the distribution of a total of 385 vascular plant species was depicted on 112 maps. A shorter and more suitable for field work version of the guide was published 14 years later (SNARSKIS, 1968a). P. Snarskis prepared and published not only guides to native plants, but also introduced ornamental plants (Ribokatte \& Snarskis, 1960; Snarskis \& Galinis, 1974). All P. Snarskis' guides were more valuable for the following reasons: 1) comprehensive identification keys; 2) a wide variety of habitats; 3 ) primary distribution data. The importance of Snarskis guides remains high. After Snarskis, only one guide of this kind was published (LeKAVIČIUS, 1989).

The P. Snarskis' Guide (1954) is sometimes referred to as the Minor Flora of Lithuania, which laid a solid foundation in the multi-volume monograph Flora of the Lithuanian SSR (1959-1980, Vol. 6). P. Snarskis was actively involved in the preparation of the Flora. Reviewing the Caryophyllaceae family, he noted morphological variation of the species and described new varieties of the species Stellaria graminea L., Saponaria officinalis L. and Silene tatarica (L.) Pers.; and new form of Spergula vulgaris Boenn. (SNArsKis, 1961a). Analysing the Orchidaceae family, he described the new variety of Orchis incarnata L. and new forms of Epipactis heleborine (L.) Crantz, E. atrorubens (Hoffm.) Besser and Orchis fuchsii Druce (SNARSKIS, 1963). Later in the Flora of the Lithuanian SSR, P. Snarskis reviewed the genera Alchemilla, Amelanchier Medik., Aphanes L., Chaenomeles Lindl., Cotoneas- ter Medik., Cydonia Mill., Malus Mill., Mespilus L., Pyracantha M. Roem., Pyrus L. (SNArskis, 1971), and with co-authors the Aronia Medik., Sorbus L. (Butkienè \& Snarskis, 1971) and Crataegus L. (ButKus \& SNARSKIS, 1971) from the family Rosaceae. He paid particular attention to the Alchemilla genus and described protologues of two new species (A. flavescens $\mathrm{Sn}$. and A. viridifolia $\mathrm{Sn}$.), three varieties and 18 forms (SNARSKIs, 1971) (Fig. 4).

During his fruitful scientific career, P. Snarskis published 60 works (Š́ARKiniené \& ButKus, 1999). His papers were about rare and limited distribution species, analysing their relationship with other species in habitats (JANKEVIČIENĖ \& LAZDAUSKAITÉ, 1999). He was the first to deal with the protection of Lithuanian endangered habitats (KLIMAVIČIŪTE, 2002) and wrote about economic botany, the history of Lithuanian botanical science, Lithuanian botanical terminology and educational methodology.

P. Snarskis described communities with endangered species such as Sesleria caerulea (L.) Ard. (SNARSKIS, 1941), published data on the distribution of species and their habitats, and analysed the causes of their extinction (SNARSKIS, 1949, 1958). P. Snarskis studied the distribution pattern and habitats of Linnaea borealis L. (SNARSKIS, 1961b), Empetrum nigrum L. (SNARSKIs, 1962), Deschampsia flexuosa (L.) Trin. (SNARSKIs, 1964a), Bistorta major Gray (SNARSKIS, 1968b), Holcus lanatus L. (1969a), Viscum album L. (SNARSKIS, 1969b). He also analysed Viccia cassubica L., Lathyrus niger (L.) Bernh., Digitalis ambigua Murray (1969c), Geranium sanguineum L. and Peucedanum oreoselinum (L.) Moench (SNARSKIS, 1964b), Asperula odorata L. and Sanicula europaea L. (SNARSKIS, 1967). Another essential work published after P. Snarskis' death was a monograph on oak forests (1972), their distribution and emergence, spruce and pine ratio, and floristic diversity.

In 1959, P. Snarskis was awarded the title of Merited Researcher, and in 1965 - the State Science Prize of the Lithuanian SSR (KLIMAVIČIŪTé, 2002). On 17 November 1969, Professor P. Snarskis passed away and was buried in Rasos Cemetery, Vilnius (Butkus \& Merkys, 1999). P. Snarskis' contribution to the development of botany in Lithuania was and still is highly valued by his colleagues and students. Two species have been named in honour of P. Snarskis: Alchemilla snarskisii Czerep. (Cherepanov, 1981) 
A. flavescens Sn. sp. nova.

Planta perennis, $15-20 \mathrm{~cm}$ in altitudinem. Rhizoma crassum, breve. Caules 2, erecti aut assurgentes, firmi, usque ad pedicella perpendiculariter pilosi. Petioli in altitudinem $2 / 5-1 / 2$ caulis, firmi, perpendiculariter omnino pilosi. Folia basilaria $4-5$, rotunda, rotundato-reniformia aut reniformia, $2-4 \mathrm{~cm}$ in longitudinem et $3,5-7 \mathrm{~cm}$ in latitudinem, rugosa, flavescentia, bilateraliter dense-pilosa, sine fisuris aut cum obsoletis fisuris in incisuris inter lobos, (7) 9-1oba. Lobi breves, in longitudinem $1 / 5-1 / 4$ laminae, hemisphaerici, arcuati aut obtuse-triangulati, cum denticulis 5-6 geminatis, parvis, acutis. Intervallum inter lobos basilares angustum. Folia caulina brevia. Inflorescentia angusta, acervi florum densi; flores (2) 3 (4) $\mathrm{mm}$ in latitudinem, flavescentes; pedicelli $1-2 \mathrm{~mm}$ in longitudinem, nudi; hypanthia dense-pilosa, sepala apice piloso.

Typus: Lituania, distr. Vilnius, prope Mickūnai, 1.VH1960 1eg. P. Snarskis; in herbario Universitatis Vilnensis conservatur. 53 Lietuvos TSR flora IV $t$.

Fig. 4. The protologue of a new species, Alchemilla flavescens Snarskis 1971 non Buser 1894 (= A. snarskisii Czerep.), by SNARSKIS (1971)

and Solidago ×snarskisii Gudž. \& Žaln. (GUDŽINSKAS \& ŽAlneravičius, 2016). Memoirs of Povilas Snarskis have been published (BuTKus, 1999). In 2006, his former students placed a bench in the Botanical Garden of Vilnius University, remembering the lecturer's scientific activities and sincere concern for students (AnONymous, 2019b).

During the active years of Povilas Snarskis, the social situation in Soviet Lithuania was difficult. The surviving Lithuanian intelligence had to make compromises and sacrifices. From the memoirs of prominent members of the botanical scientific community (Minkevičius, 2003; DAGYs, 2006; NAtKeviČAitėIVANAUSKIENE⿺, 2008), we see that the task was difficult. Many intellectual researchers did not survive the World War II (VAILIONYTE, 2011; KupREVIČIUS, 2014; NAujalis \& RimgailĖ-VoICIK, 2016) or were forced to leave Lithuania (ZEMANEK \& KöHLER, 2019).

We believe that it is necessary to recognise the importance of P. Snarskis' research for Lithuanian botanists and to remind the scientific community about this extremely dedicated and voluntary personality. P. Snarskis was an innovator, who used his logic and creativity and constructed guidelines to achieve his goals in difficult historical times.

\section{REFERENCES}

Anonymous, 2019a: Virtuali Pasvalio krašto kultūros paveldo informacijos sistema http://www.pasvalia.lt/gidas/en/objects/423-roofed-pole-to-abiologist-professor-povilas-snarskis [Assessed 2019-09-15]

Anonymous, 2019b: Vilniaus universiteto Botanikos sodas, suoliukų sąrašas https://www.botanikossodas.vu.lt/lankymas/suoliukai-suoleliai [Assessed 2020-03-10]

ButKienE S., SnARSKIS P., 1971: Šermukšnis - Sorbus L.; Aronija - Aronia Pers. - In: NatKeviČAitėIvanAuskienĖ M. (ed.), Lietuvos TSR flora, 4: 245-252. - Vilnius.

Butkus V. (ed.), 1999: Profesorius Povilas Snarskis. - Vilnius.

Butkus V., Merkys A., 1999. Profesoriaus Povilo Snarskio gyvenimo kelias. - In: ButKus V. (ed.), Profesorius Povilas Snarskis: 7-13. - Vilnius.

Butkus V., Snarskis P., 1971: Gudobelè - Crataegus L. - In: NATKEVIČAitė-IvanAuskienĖ M. (ed.), Lietuvos TSR flora, 4: 263-294. - Vilnius.

Cherepanov S. K., 1981: Alchemilla snarskisii Czerep. - In: Cherepanov S. K., Sosudistye rastenija 
SSSR. [Vascular Plants of the Soviet Union]: 431. - Saint Petersburg.

DAGYs J., 2006: Dienoraštis. - Vilnius.

GudŽInSKAS Z., ŽaLnERAVIČIUS E., 2016: Solidago $\times_{\text {snarskisii nothosp. nov. (Asteraceae) from }}$ Lithuania and its position in the infrageneric classification of the genus. - Phytotaxa, 253(2):147155.

JANKEVIČIENĖ R., LAZDAUSKAITĖ Ž., 1999: Profesoriaus Povilo Snarskio darbai teorinès botanikos srityje. - In: Butkus V. (ed.), Profesorius Povilas Snarskis: 13-30. - Vilnius.

JANKEVIǏIENĖ R., LeKavičIUs A., 1977: Augančiu LTSR teritorijoje aukštesniųjų augalų rūšių inventorizacija ir floristiniai tyrimai per 25 metus. - In: JANKEVIČIUS K. (ed.), Botanikos mokslų pasiekimai tarybų Lietuvoje. - Vilnius.

JANONIS A., 1999: Profesoriaus Povilo Snarskio mokymo metodika. - In: ButKus V. (ed.), Profesorius Povilas Snarskis: 13-30. - Vilnius.

KLIMAVIČIŪtĖ J., 2002: Botanikos mokslo raida Lietuvoje 1919-1943 m. - Vilnius.

Kuprevičıus J. (ed.), 1934: Vadovas augalams pažinti. - Kaunas.

KuPREVIČIIUS G., 2014: Koncertas. - Vilnius.

LEKAVIČIUS A., 1989: Vadovas augalams pažinti. Vilnius.

MinkEvičIUs A., 2003: Mano gyvenimo nuotrupos. Kaunas.

NATKEVIČAitė-IvanauskienĖ M., 2008: Tiesa skins kelią sau. - Kaunas.

Naujalis J. R., Rimgailè-Voicik R., 2016: Plant community associations and complexes of associations in the Lithuanian seashore: retrospective on the studies and tragic fate of the botanist Dr Abromas Kisinas (1899-1945). - Israel Journal of Plant Sciences, 63(3):167-175.

Ribokaitė B., Snarskis P., 1960: Dekoratyviniai vijokliniai ir laipiojantieji augalai. - Vilnius.

RIČKIENE A., 2003: Botany science in Lithuania in 1944-1965. - Vilnius.

RIČKIENĖ A., 2017: Botanists in Lithuania during the Michurinist Campaign. - Endeavour: 41(2): 51-65.

SNARSKIS P., 1939: Lietuvos rasakilos (Alchemilla) ir jų išsiplatinimas. - Vytauto Didžiojo universiteto Matematikos-Gamtos fakulteto darbai, 13(2): 183-347.
SNARSKIs P., 1941: Sesleria coerulea subsp. uliginosa Čelakovsky išsiplatinimas Lietuvoje. - Vilniaus universiteto Matematikos-Gamtos fakulteto darbai, 1(14): 151-162.

SNARSKIS P., 1948: Vadovas Lietuvos TSR laukų piktžolėms pažinti. - Vilnius.

SNARSKIs P., 1949: Naujos retesniujų LTSR augalų augimo vietos. - Vilniaus valstybinio universiteto mokslo darbai. Gamtos ir matematikos mokslu serija, 1: 171-185.

SNARSKIs P., 1954: Vadovas Lietuvos TSR augalams pažinti. - Vilnius.

SNARSKIS P., 1958: Kai kurie retesnieji augalai LTSR floroje. - Vilniaus valstybinis pedagoginis institutas. Mokslo darbai, 7: 173-183.

SNARSKIS P., 1961a: Gvazdikiniai - Caryophyllaceae Juss. - In: NATKeviČAitĖ-IvanAuskienĖ M. (ed.), Lietuvos TSR flora, 3: 268-342. - Vilnius.

SNARSKIS P., 1961b: Šiaurinè linèja. - Mūsų girios, 9: 36.

SNARSKIS P., 1962: Juodosios varnauogès (Empetrum nigrum L.) paplitimas Lietuvos TSR. - LTSR aukštuju mokyklų mokslo darbai. Biologija, 2: 133-144.

SNARSKIS P., 1963: Orchidažiedžiai - Microspermales. - In: NATKEVIČAitĖ-IVANAUSKIENĖ M. (ed.), Lietuvos TSR flora, 2: 565-628. - Vilnius.

SNARSKis P., 1964a: Lanksčiosios šluotsmilgès - Deschampsia flexuosa Trin. - išplitimas LTSR. LTSR aukštųjų mokyklų mokslo darbai. Biologija, 4: 77-95.

Snarskis P., 1964b: Raudonžiedžio snapučio (Geranium sanguineum L.) ir šilinio saliavo (Peucedanum oreoselinum Moench) išplitimas Lietuvoje. - In: Kultūrinių augalų derlumo pakèlimo fiziologiniai pagrindai, 291-329. - Vilnius.

SnARSKIS P., 1967: Kvapiosios krunès (Asperula odorata L.) ir miškinès girūnès (Sanicula europaea L.) išplitimas Lietuvoje. - LTSR aukštujų mokyklų mokslo darbai. Biologija, 7: 155-180.

SNARSKIS P., 1968a: Vadovas Lietuvos augalams pažinti. - Vilnius.

Snarskis P., 1968b: Gyvatžolès (Polygonum bistorta L.) išplitimas Lietuvoje. - LTSR aukštụjų mokyklų mokslo darbai. Biologija, 8: 157-173.

SNARSKIS P., 1969a: Pūkuotosios vilnūnès (Holcus lanatus L.) išplitimas Lietuvoje. - LTSR aukštuju mokyklų mokslo darbai. Biologija, 9: 11-17.

SNARSKIS P., 1969b: Paprastojo amalo (Viscum al- 
bum L.) išplitimas Lietuvoje. - LTSR aukštujų mokyklų mokslo darbai. Biologija, 9: 19-21.

SNARSKIS P., 1969c: Kašubinio vikio (Vicia cassubica L.), saldžiašaknio pelèžirnio (Lathyrus niger Bernh.) ir didžiažiedès rusmenès (Digitalis ambigua Murr.) išplitimas Lietuvoje. - LTSR aukštųjų mokyklų mokslo darbai. Biologija, 9: 23-41.

SNARSKIS P., 1971: Rasakila - Alchemilla L.; Mažuolè-Aphanes L.; Svarainis - Cydonia Mill.; Atvaisa-Chaenomeles Lindl.; Kriaušè-Pyrus L.; Obelis - Malus Miller; Medlieva - Amelanchier Med.; Kaulenis - Cotoneaster Med.; Dyglainè Pyracantha Roem; Šliandra - Mespilus L. - In:

NatkeviČaitė-IvanauskienĖ M. (ed.), Lietuvos TSR flora, 4: 192-245, 252-263.- Vilnius.

Snarskis P., 1972: Lietuvos TSR ąžuolynai (floris- tiniu ir geobotaniniu požiūriu). - Vilnius.

Snarskis P., Galinis V., 1974: Vadovas Lietuvos dekoratyviniams medžiams ir krūmams pažinti. Vilnius.

ŠArkinienè I., Butkus V., 1999: Profesoriaus Povilo Snarskio bibliogafijos sąrašas. - In: Butkus V. (ed.), Profesorius Povilas Snarskis: 57-60. - Vilnius.

Vailionytė D., 2011: Liudas Vailionis. - Kaunas.

Zemanek A.M., KÖHLER P., 2019: Botany at Stefan Batory University in Vilna (Wilno, Vilnius) (1919-1939). - Studia Historiae Scientiarum, 18: 93-137.

\section{Archival Sources}

Lithuanian Central State Archives (LCSA), fund F631 (Vytautas Magnus University Student Files), description 7, file 839, pages 1, 2, 7 .

\section{PROFESORIUS POVILAS SNARSKIS - LIETUVOS FLOROS TYRIMAMS SKIRTAS GYVE- NIMAS}

\section{Jūratė TuPČIAUSKaIté, Radvilė RIMgaILĖ-VoICIK}

\section{Santrauka}

2019 m. sukako 130 metų nuo profesoriaus Povilo Snarskio gimimo ir 50 metų nuo šio žymaus Lietuvos floros tyrejo mirties. P. Snarskiui už darbą „Lietuvos rasakilos (Alchemilla) ir jų išsiplatinimas“" $1940 \mathrm{~m}$. buvo suteiktas daktaro laipsnis. Svarbiausios jo mokslinio darbo sritys buvo Lietuvos induočių augalų ịvairovė ir jų geografinis paplitimas. P. Snarskis paskelbė pirmuosius augalų paplitimo žemėlapius Lietuvos teritorijoje. Jis yra svarbiausių Lietuvos augalams pažinti vadovų, išleistų 1948 m., 1954 m. ir 1968 m., autorius, daugiatomio leidinio „Lietuvos TSR flora“ vienas iš autorių; iš viso paskelbe 60 mokslo ir mokslo populiarinimo darbų. Lietuvos herbariumuose yra saugoma daugiau nei 20000 P. Snarskio surinktų induočių augalu pavyzdžių. XX a. viduryje P. Snarskis aktyviai prisidejo prie profesionalios botanikos mokslo raidos, ruoše specialistus Vilniaus universitete ir Vilniaus pedagoginiame institute. P. Snarskis sudètingu istoriniu laikotarpiu dirbo kūrybingai ir novatoriškai siekdamas savo tikslų. 